\title{
Factors Affecting Customer Loyalty in the B2B Background Based Neural Network Model
}

\begin{abstract}
Jian Chen
School of Economic and Management Shanghai Polytechnic University

*Corresponding author. Email:chenjian@sspu.edu.cn

ABSTRACT

Customer loyalty is macroscopically important for all aspects of life. It is related to the continuous development of the company and the creation of the brand images. However, specific to different industries, each industry has its own issues. Industry's unique key factors affecting customer loyalty, such as the speed of product update, communication costs, transaction costs, etc. all those factors have a great impact on customer loyalty. This paper collects and collates the literature on the analysis of customer loyalty in various industries and combines the characteristics of the company. According to the collected data, the use of neural network statistics affects loyalty. The factors were also verified by a certain simulation.
\end{abstract}

Keywords: Customer loyalty, Neural network, Impact factors.

\section{CUSTOMER LOYALTY}

Customer loyalty is that customers have relatively high satisfaction after experiencing the products and services provided by the company, resulting in a psychological dependence on the company's products and services. When purchasing this type of products and services for the second time or many times in the future, they are often used to giving priority to the company, and there is a tendency of repeated purchase over time. Because of the affection and habit of materials or services to the customers, it is essentially expressed through customers' sentimental loyalty, physiological loyalty and responsive loyalty. Among them, emotional loyalty is manifested in the high recognition and satisfaction of customers with the concept, behavior and positive imagination of the enterprise; Behavioral loyalty is manifested in the repeated purchase of products and services by customers when they consume again; Conscious loyalty is expressed in the future consumption intention of customers for the enterprise's products and services. Eventually the psychological dependence and behavioral pursuit of customers on brands or suppliers (service) because they accept these high rated products or services because these meet their own needs perfectly. Among them, loyal customers refer to those customers who can refuse the price concessions provided by their peers, continue to buy their own products or services, and even voluntarily publicize for the enterprise.
Customer loyalty is the core fundamental bone of customer loyalty in every marketing activity. It is a measure of consumers' feelings for products, highly shifting the potential possibilities of consumers switch to another competitive brand. Especially when the product or service changes in price or in product characteristics or both, with the increase of loyalty to products or services, the influence of fundamental consumers on competitive behavior decreases which means get advantage in a market. Hence, customer loyalty is a pointer of the product or service which company provides that reflects the relationship between consumer loyalty behavior and future profits, because loyalty to enterprise products or services can be easily transformed into future market sales. To the most companies in the world, create and maintain customer loyalty is the most effective and lest cost way to achieve profit growth. Enterprises must transpose the concepts and methodologies of doing transactions into the concept of establishing positive relations with consumers, from the basic step by only focusing on the questions and get consumers to focusing on the loyalty and perseverance of consumers. 


\section{FACTORS AFFECTING CUSTOMER LOYALTY IN THE INDUSTRY}

Research grasping the influencing factors of customer loyalty plays an important role in improving customer loyalty. In recent years, domestic and foreign scholars' research on the influencing factors of customer loyalty mainly includes the following points:

\subsection{Product and Service Quality}

Product and service quality is the basic material that direct influence the loyalty of customers. The research shows that there is a positive correlation between product and service quality and has potential impulse to pay higher prices or continue to keep loyalty in the case of rising prices to the fixing level. There are differences in the correlation between product and service quality and customer loyalty among different industries.

\subsection{Customer Satisfaction}

The level of customer satisfaction is the part of expected performance and expected difference. It also is the core and ground issue of customer loyalty. The "service profit chain" model of haskett and other scholars clearly puts forward that customer satisfaction can directly leads to customer loyalty. Under different competition intense level, the effect of customer satisfaction on customer loyalty is quite erratic, which can easily be broken by cheaper price and high-quality services.

\subsection{Customer Delivered Value}

Customer delivered value refers to the difference between total customer value and total customer cost. Total customer value refers to a group of benefits expected by customers to buy a certain product and service. It may include product value, service value, personnel value, image value and so on, In General Speaking, it depends on the price of product and level of service.

\subsection{Switching Cost}

Switching cost can be understand as the one-time cost faced by buyers when they switch from one supplier to another, the cost here includes many aspects like asset, time, feeling, etc. the amount of switching cost has a direct impact on maintaining customer loyalty. The irreplaceable nature of characteristic products or services can greatly enhance customer loyalty. Successful company should build a successful switching cost strategy because buyers need to change all the used-to-be behaviors and may cost more money and spend more time.
And this paper summarizes these four factors into table1.

\section{MODEL SELECTION}

Artificial neural network (abbreviated as ANN), abbreviated as neural network (abbreviated as $\mathrm{NN}$ ) or neural like network, is a mathematical model that simulates the structure and functions of biological neural network which basically simulates how central nervous system especially brain learns and correct errors from training ground), which is used to estimate or forecast the questions.

Neural network is mainly composed into three layers which are input layer (for input data), hidden layer(for mathematical calculation) and output layer(provides answers, which are classification answers). When there is only one hidden layer, the network is a two-layer neural network. Because the input layer does not make any transformation, it can not be regarded as a separate layer. Inside the neural network, each neuron in the network of input layer combined as a feature of input data, and the number of output layers represents the number of classification labels. These labels are designed or predefined for classification choices while the number of hidden layers and hidden layer neurons are manually set by adjust the mathematical result for minimal errors. The figure shows below:

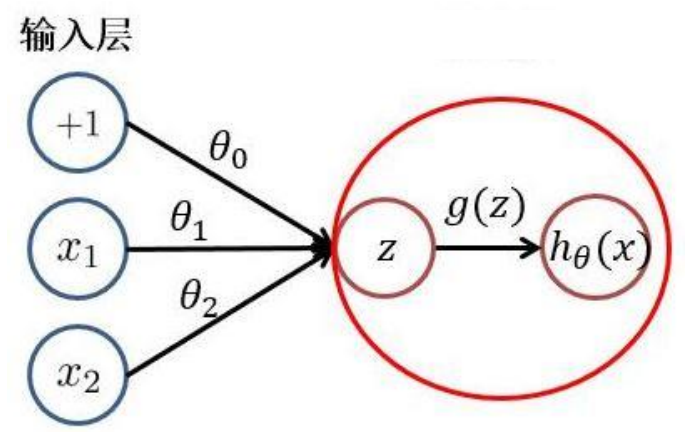

Figure 1 Neural Network layer and parameter display.

\section{DATA SELECTION AND PREPARATION}

All data we collected from real transaction and in-site research. And totally we collect about 800 records, and we put 500 as training records, 100 as test records, 200 as validation records. And the Loyalty will be categorized into two level: High, means high loyalty has highly possibility stick with suppliers, Low means low loyalty which possible change suppliers.

The training records are showed as follow: 


\section{MODEL DESIGN}

According to the data we organized, the following neural network be designed, with 7 inputs nodes with one bias input, 7 hidden layers nodes and output layer with two classified nodes.

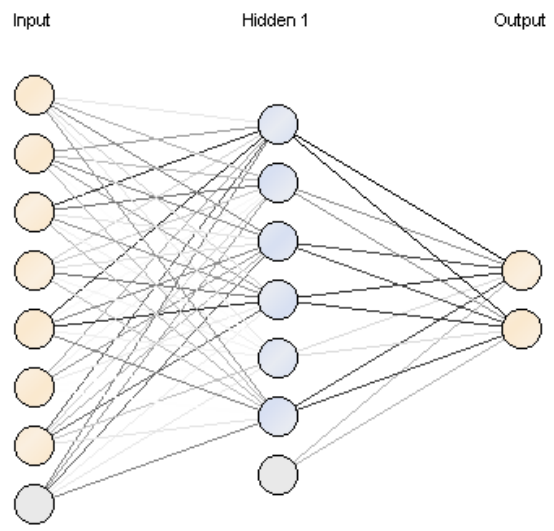

Figure 2 Optimized Neural Network Model

Once the network structure defined, we put this structure into rapidminer software to illustrate the result and make evaluation of the model:

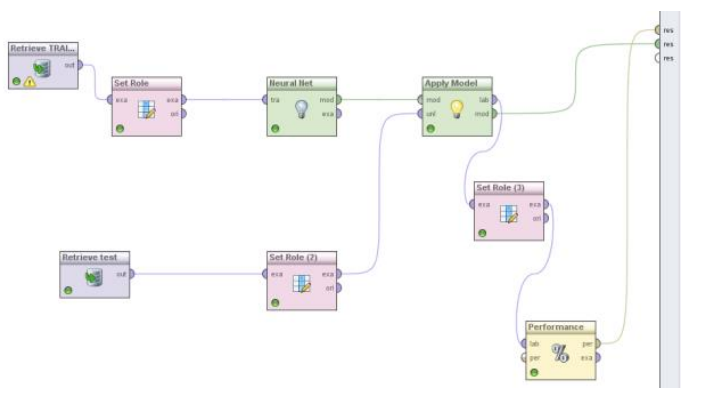

Figure 3 System Design of Neural Network

Which 500 training cycles and 0.3 learning rate. The performance of the model is as follow:

Table 3. Training Result

\begin{tabular}{|c|c|c|c|}
\hline & trueH & trueL & $\begin{array}{c}\text { Class } \\
\text { precision }\end{array}$ \\
\hline predH & 40 & 7 & $85.10 \%$ \\
\hline predL & 9 & 44 & $83.02 \%$ \\
\hline Class recall & $81.63 \%$ & $86.27 \%$ & \\
\hline
\end{tabular}

And with average rate of recall and precision are over $80 \%$. That rate is quite acceptable.

\section{CONCLUSION}

This paper introduces the Factors Affecting Customer Loyalty in the B2B Background Based Neural Network Model. Utilizing this model, 500 training data sets be adopted and this model be trained with an average of over $80 \%$ recall and precision for two categories. Therefore, this model can be used for the proper circumstances.

\section{ACKNOWLEDGMENT}

This paper is sponsored by Cultivation of innovative talents - Construction of first-class courses under Grant No.A30db21103-0314).

\section{REFERENCES}

[1] The Research of Customer Loyalty Improvement in Telecom Industry Based on NPS Data Mining [J] 2017, 14(11):260-268.

[2] LIYI ZHANG, KUNLIN LI, YAN YE. Research on Customer Loyalty of Online Short-term Rental Service: A Meta-analysis[C]. //The Eighteenth Wuhan International Conference on E-Business. 2019:342-349.

[3] NADINE SCHIRMER, CHRISTIAN M. RINGLE, SIEGFRIED P. GUDERGAN, et al. The link between customer satisfaction and loyalty: the moderating role of customer characteristics [J]. Journal of strategic marketing, 2018, 26(4):298-317.

[4] PARIHAR, PRATEEKSHA, DAWRA, JAGROOK, SAHAY, VINITA. The role of customer engagement in the involvement-loyalty link [J]. Marketing intelligence \& planning, 2019, 37(1):66-79. DOI: 10.1108/MIP-11-2017-0318.

[5] NATALIA RUBIO, NIEVES VILLASENOR, MARIA JESUS YAGILE. Customer's loyalty and trial intentions within the retailer: the moderating role of variety-seeking tendency [J]. Journal of consumer marketing, 2019, 36(5):620-632. DOI: 10.1108/JCM-10-2017-2391.

[6] MILMAN, ADY, TASCI, ASLI, ZHANG, TINGTING (CHRISTINA). Perceived robotic server qualities and functions explaining customer loyalty in the theme park context [J]. International journal of contemporary hospitality management, 2020, 32(12):3895-3923. DOI: 10.1108/IJCHM-062020-0597.

[7] LU, CHIH-CHENG, WU, ING-LONG, HSIAO, WEI-HUNG. Developing customer product loyalty through mobile advertising: Affective and cognitive perspectives $[\mathrm{J}]$. International journal of 
information management, 2019, 47(Aug.):101-111. DOI:10.1016/j.ijinfomgt.2018.12.020.

[8] FAZLUL K. RABBANEE, OKSANA BURFORD, B. RAMASESHAN. Does employee performance affect customer loyalty in pharmacy services? [J]. Journal of Service Theory and Practice, 2015, 25(6):725-743. DOI: 10.1108/JSTP-06-2014-0126.

[9] YANG, SHUIQING. Understanding B2B customer loyalty in the mobile telecommunication industry: a look at dedication and constraint $[\mathrm{J}]$. Journal of business \& industrial marketing, 2015, 30(2):117128. DOI: 10.1108/JBIM-05-2013-0105.

[10]SARRA BERRAIES, RACHED CHTIOUI, KARIM BEN YAHIA. Functional Characteristics of Banking Websites and Customer Loyalty: The Mediating Role of Online Trust [J]. The journal of applied business research, 2015, 31(3):911-923. 